\title{
Regional turbidites and turbiditic environments developed during Neogene and Quaternary in Croatia
}

\section{Regionalni turbiditi in turbiditna okolja, razviti v Neogenu in Kvartarju na ozemlju Hrvaške}

\author{
Tomislav Malvić1,** \\ ${ }^{1}$ Faculty of Mining, Geology and Petroleum Engineering, University of Zagreb, Pierottijeva 6, 10000 Zagreb, Croatia \\ *tomislav.malvic@rgn.hr
}

\begin{abstract}
The Croatian Neogene and Quaternary depositional sequences preserve a record of several different depositional environments with turbidite successions. These are turbiditic systems developed during the Late Miocene in the Croatian part of the Pannonian Basin System and during the Pliocene and Pleistocene in the northern Adriatic Sea. The shape, salinity and depths of depositional areas were significantly different in these two depressional areas, but both were fed mostly with Alpine detritus. Neogene turbidites with lacustrine pelitic sedimentation formed thick heterogeneous sequences of sandstones and marls (totalling several hundreds to some thousands of metres in thickness in different depressional parts) of Upper Miocene age in Northern Croatia. By contrast, Pliocene and especially Pleistocene turbidites of the northern Adriatic were deposited in a marine environment where the total thickness of sand and clay sequences can reach up to several thousand metres. In both cases, individual sandy or sandstone turbiditic sequences (events) can reach several tens of metres in thickness. These turbidite clastic sediments are important hydrocarbon reservoirs.
\end{abstract}

Key words: siliciclastics, Pannonian Basin System, Po Depression, Upper Miocene, Pliocene, Quaternary

\section{Izvleček}

Neogenska in kvartarna sedimentacijska zaporedja na Hrvaškem vsebujejo zapis o nekolikih različnih sedimentacijskih okoljih s turbiditnim zaporedjem. Gre za turbiditne sisteme, razvite za časa poznega miocena $v$ celinskem hrvaškem delu, in v pliocenu in pleistocenu na območju severnega Jadranskega morja. Oblika sedimentacijskih prostorov, slanost in globine so se bistveno razlikovali med tema dvema udorinskima območjema, ki so se pa oboja zapolnjevala s pretežno alpskim drobirjem. Neogenski turbiditi jezerske pelitne sedimentacije so tvorili debela heterogena zaporedja peščenjakov in laporovcev (debeline nekaj sto do nekaj tisoč metrov v različnih delkih udorine) zgornjemiocenske starosti v severni Hrvaški. Nasprotno so bili pa odloženi pliocenski in zlasti pleistocenski turbiditi severnega Jadrana v morskem okolju, v katerem skupne debeline peščenih in glinenih zaporedij znajo doseči nekaj tisoč metrov. V obeh primerih znaša debelina posameznih turbiditnih dogodkov do nekaj deset metrov. Ti turbiditni klastični sedimenti so pomembni rezervoarji ogljikovodikov.

Ključne besede: silikatne klastične kamnine, sistem Panonske kadunje, Padska udorina, zgornji Miocen, Pliocen, Kvartar 


\section{Introduction}

Two regions in Croatia are the sites of significant and economically important turbiditic sedimentation that occurred during the Neogene and Quaternary. These are (a) the Croatian part of the Po Depression in the northern Adriatic Sea and (b) the Croatian part of the Pannonian Basin System (CPBS), which approximately covers the entire Northern Croatia (Figure 1). As these turbiditic sediments and deposits are
Po Depression, which played the most crucial role in defining their sealing properties as well as structural forming. In both cases, turbidite sequences reached tens of metres in thickness, transporting detritus from the Alps. However, depositional palaeogeography differed significantly, strongly influencing the distribution of, especially, sandy clastics. The principal published findings are compiled in this review, and the main similarities and differences between these two areas are outlined.

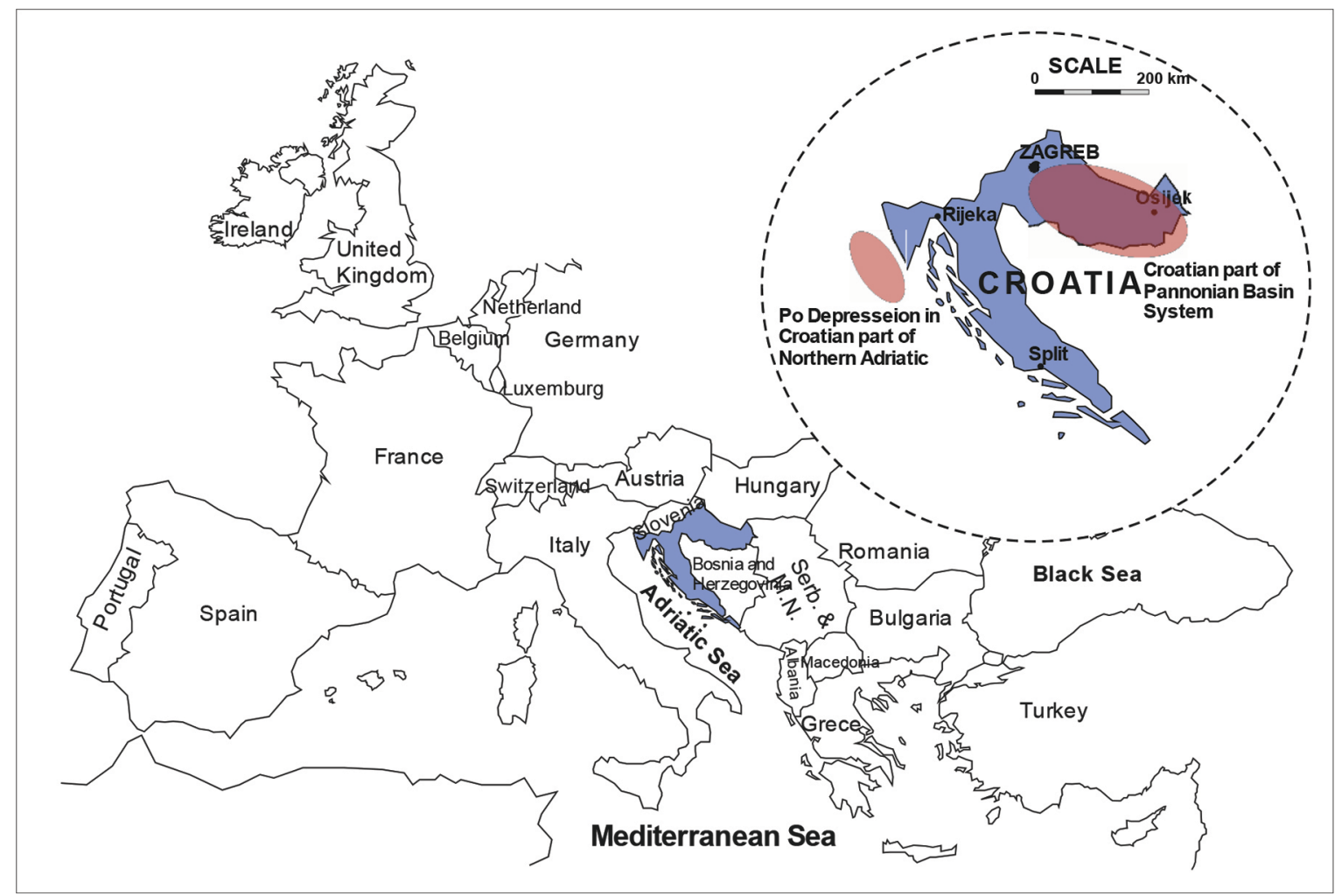

Figure 1: Areal extension of analysed turbiditic sequences in Croatia.

geologically relatively young (both were deposited in the Late Cenozoic), the sedimentological features and process are still clearly evident and easily interpreted from well-preserved sequences, mostly in deep wells. These well-studied environments are described in numerous published results, especially for the Croatian part of the Pannonian Basin System. Numerous hydrocarbon reserves have been discovered in both turbiditic systems, and so a large database of geophysical well logs, core and seismic data are available for interpreting these turbidite systems. Deposits are consolidated in the CPBS and just very slightly or unconsolidated into the

\section{Geological setting in Northern Croatia and the northern Adriatic}

Neogene and Quaternary sediments in the CPBS are grouped into three megacycles [1,2], each with its characteristic depositional lithofacies, depositional environment and chronostratigraphic age. Generally, the total thicknesses of the megacycles are in the range of 500-1,500 m at the margins of depositional depressions, up to $3,500 \mathrm{~m}$ in central areas of the SlavoniaSrijem Depression, 5,500 $\mathrm{m}$ in the Sava and Mura Depressions and approaching 7,000 m in the Drava Depression [2]. The use of the 
term 'depression' here follows published Croatian usage. 'Depression' generally describes a regionally downwarped area with elongated or irregular margins, whereas the term 'basin' is used for slightly elliposoidal or rhomboidal shapes of such macrostructures. Each megacycle comprises characteristic sediments of one supercycle of relative sea-level change, characterized by a gradual rise in sea level followed by a relatively abrupt fall, connected with two transtensional and transpressional phases in the CPBS. Due to the similarity between the depositional environments in the depositional depressions throughout Croatia, the correlation between megacycles and lithostratigraphic units was relatively straightforward. The first (oldest) megacycle [1] lasted for most of the Badenian (3.4 Myrs), which can be extended to possible, local, non-marine sediments of the Lower Miocene. It is characterized mostly by coarse-grained clastics (breccia, conglomerates or sandstones) in the older parts and fine-grained and pelitic clastics (clays, marls, calcitic marls, sandy and clayey marls with tuff intercalations) or limestones (Lithothamnium) in chronostratigraphic younger areas; these clastics are often source rocks [3]. The second megacycle was deposited during the Pannonian and Pontian, with uniform, homogeneous deposition of turbiditic sandstones or siltites and hemipelagic marls over approximately 5.9 Myrs [1]. A brackish lacustric environment existed throughout the Pannonian, becoming a freshwater environment in the Pontian [2]. Lakes were up to $200 \mathrm{~m}$ deep [4], with approximately equal rate of sedimentation and subsidence. The third megacycle of the Pliocene and Quaternary periods lasted approximately 5.6 Myrs [1]. Mostly, clayey limestones, finegrained sandstones and sands were deposited as the oldest sediments and were overlain by gravels, sands, silts clays and loess.

In the northern Adriatic, Neogene and Quaternary sediments have considerable thicknesses, whereas the Pliocene and Pleistocene sequences can reach a thickness of $6,000 \mathrm{~m}$. These were deposited in numerous Miocene and Pliocene Depressions in the Adriatic Basin, especially in the largest Po Depression, which is today located in the Italian offshore and onshore and offshore Croatia. The entire depression is gen- erally characterised by hemipelagic Pliocene and Pleistocene sequences of mud, clay, marls, marly limestones and turbiditic sands and silts deposited mostly by progradations of the Po palaeodelta and sporadically by the Adige and Piave Rivers. Turbidite deposition was highly influenced by evolution of the Adriatic Sea during the Miocene, Pliocene and Quaternary. Depression was eventually formed in the Holocene following the Flandrian transgression [5-7]. However, the oldest rocks proven to be present in the basements of the Adriatic Basin were deposited within carbonate platform environments; there were different types of carbonate platforms located in different palaeogeographical settings. Carboniferous to Middle Triassic mixed siliciclastic-carbonate deposits were accumulated along the Gondwanian margin, on a spacious epeiric carbonate platform [8]. In the Middle Triassic, a huge isolated carbonate Southern Tethyan Megaplatform (abbreviated as STM) was formed, with the area of the future AdCP located in its inner part, existing from the end of the Ladinian to late Early Jurassic (Toarcian), when several carbonate platforms (including the Adriatic, Apenninic and Apulian) were created [8]. Later, they were separated by newly drowned deeper marine areas (including the Adriatic Basin), and sedimentary succession was continued by sediments of the Adriatic Carbonate Platform, which range in age from Toarcian to uppermost Cretaceous [8]. A transgression in the Early Palaeogene reactivated marine sedimentation only locally, but the uplift led to the onset of clastic sedimentation, which persisted into the Miocene, Pliocene, Pleistocene and Holocene, but with different detritus sources. Sediments of Palaeocene to Miocene age can be found only locally and mostly in deeper parts represented by carbonates. In contrast to this, Pliocene, Pleistocene and Holocene deposits cover the entire Po Depression, reaching significant thicknesses of up to $6,000 \mathrm{~m}[2,9]$ in the Italian part of the depression and consisting of marlstones, clay (stones), silt (stones) and sand (stones) [10]. A general mechanism of turbidites (gravity flows) can be applied for the reconstruction of analysed environments. Depositional processes in general [11-14] and in comparison with other regions and models are especially well 


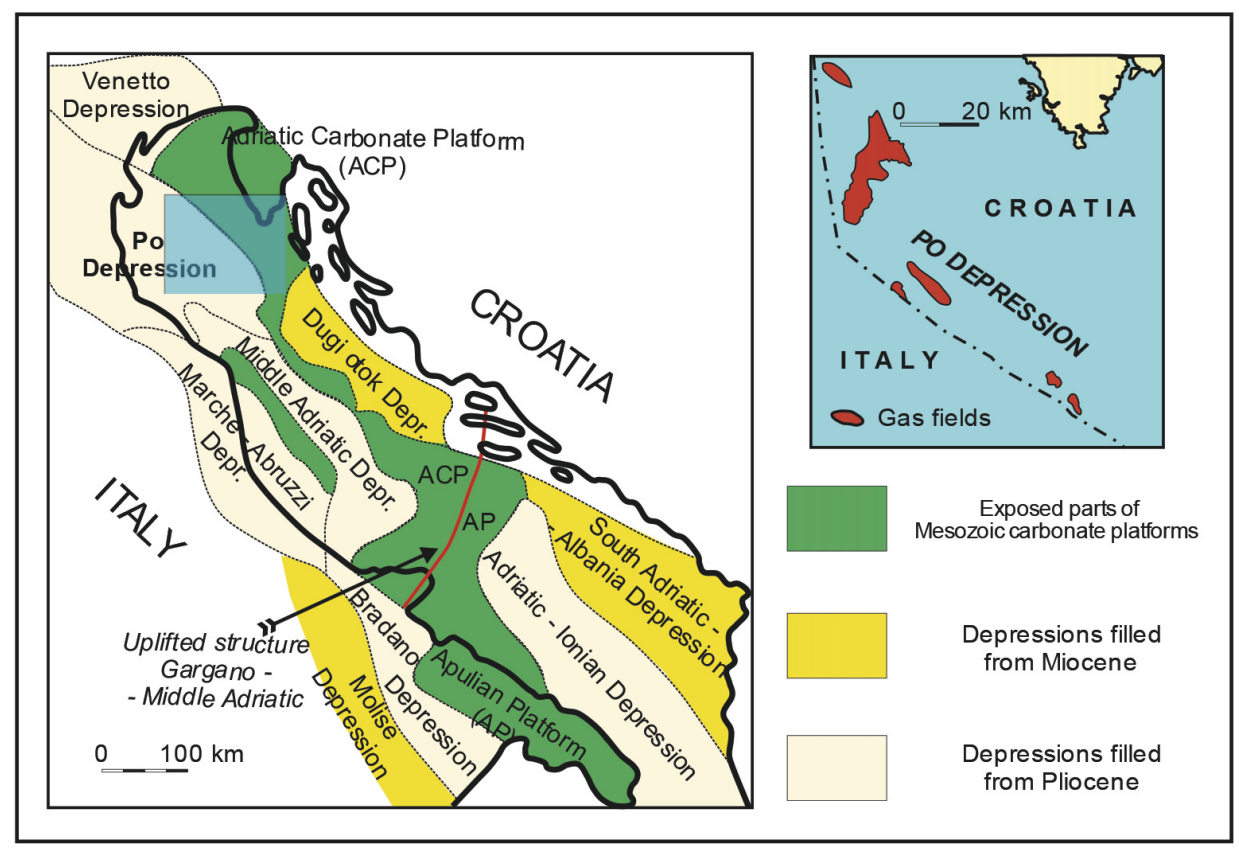

Figure 2: Miocene-Quaternary depressions in the Adriatic Basin (left) and analysed part of the Po Depression (right) in the Croatian offshore (compiled after Prelogović and Kranjec [10]; Velić and Malvić [15]).

documented for the CPBS [15]. In [4, 16-18], four characteristic turbidite facies of pure, medium-grained sandstones $\left(F_{1}\right)$, laminated sandstones, siltstones and marls $\left(F_{2}, F_{3}\right)$ and pure marls $\left(F_{4}\right)$ are clearly distinguished. Two principal lithofacies have been defined for the northern Adriatic, namely, pelitic (mud and clay) and psammitic (silt and sand) [15]. These two general lithofacies can be easily compared with 'classical' turbidites deposited in distal delta or prodelta settings from low-density currents, containing fine-grained sediments of the classic [19] sequence, including Tc, Td and Te. These sediments are regularly interbedded with interturbiditic, hemipelagic interval Tf described by [20], deposited during periods of low or very low psammitic and overall sediment supply caused by delta retrogradation (allocyclic process) or lateral (autocyclic process) movement due to sea-level rise. In the Po Depression, turbiditic and hemipelagic lithofacies are divided in a very detailed manner into seven lithofacies [9] characteristic for Croatian northern Adriatic. They are named as mud conglomerates (MK), massive mudstones (MS), sands with 'rip-up' clasts (KP), massive sands (MP), thin-layered sands, silts and muds (TPSM), muds and silty muds (SM) and hemipelagic muds (HM).

\section{Pliocene and Pleistocene turbidite systems of the Croatian northern Adriatic}

\section{Materials and methods}

The Adriatic Basin is divided into sub-basins or, as it is usually termed in the literature, depressions of different ages. The Dugi Otok, South Adriatic-Albania and Molise Depressions were initiated in the Miocene, while the Venetto, Po, Marche-Abruzzi, Middle Adriatic, Bradano and Adriatic-Ionian Depressions (Figure 2) developed from Pliocene times onwards [10]. Today, the largest depressions are the Po and South Adriatic-Albania. In the northern Adriatic, that is, Croatian part of the Po Depression, deposition, especially from Pleistocene, is strongly dominated by turbiditic events generated in the Po prodelta, replacing mostly low-sediment basinal supply during Pliocene.

At the end of Miocene (5-6 Ma ago), glaciation in the Antarctic, when ice volumes increased beyond those of the present day, was related to 'global climatic cooling, a rapid northward movement of about $300 \mathrm{~km}$ of the Antarctic Convergence, and a eustatic sea level drop that may have been partly responsible for the isolation of the Mediterranean basin' [21, abstract page]. The Northern Hemisphere, especially 


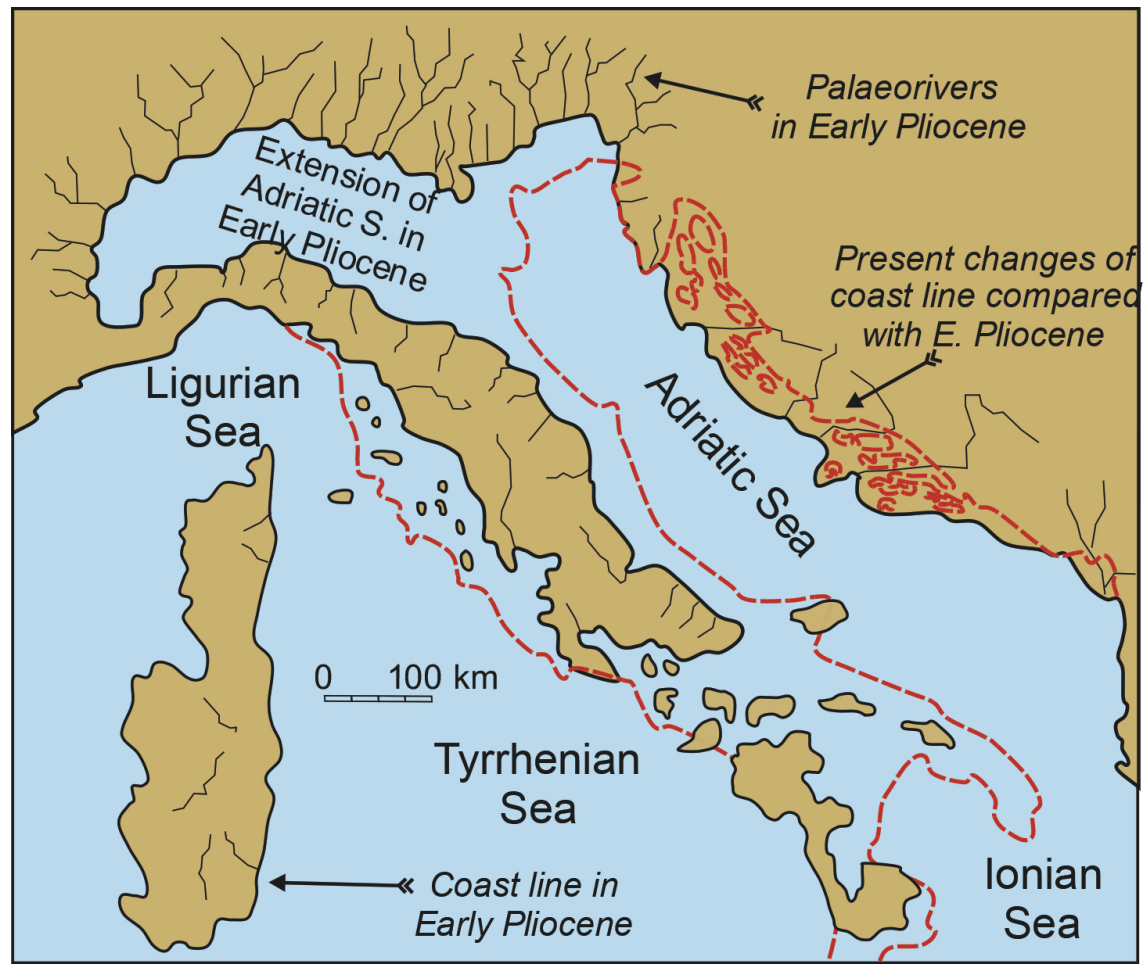

Figure 3: Adriatic Sea borders in Lower Pliocene (slightly modified from Velić and Malvić [15]).

the inland of North America [22], had been subdued to glaciation(s) that caused a global sea-level fall of several tens of metres. Consequently, the connection through the Strait of Gibraltar between the Atlantic and the Mediterranean was interrupted, and Mediterranean shallow environments were filled by large quantities of evaporites during this Messinian salinity crisis, reducing marine areas to less than half their previous extent. Veseli has described the impact of the Messinian salinity crisis in the Adriatic [23]. Connection between the Mediterranean and the Atlantic was re-established at the end of Messinian due to the Early Pliocene global sea-level rise; marine environments then spread throughout the basin. This overall flooding was reflected in the margins of the palaeo Adriatic Sea (now the Adriatic Basin), which covered a larger area than the area that is covered today, especially in the Alpine region and around the Gargano Peninsula (Figure 3). As a result (Figure 2), a significant part of the Po Depression is now located onshore, between the Southern Alps and the Apennines, while in the Pliocene this was below sea level. Sediments of Pliocene (5.332-2.588 Ma) age in the Croatian northern Adriatic are pelitic and are characterized by numerous foraminifera in the Lower Pliocene, which indicates a warm climate and sedimentation in a relatively deep and open sea outer shelf setting [24,25]. Upper Pliocene sediments show a decrease in diversity and quantity of planktonic foraminifera [26] because of the moderately cold climate caused by the first glaciation (Biber, about 2.5 Myrs). Pliocene sediments are thicker (Figure 4.2 in [9], modified from [27]) on the western side (Italian off and onshore), due to rapid subsidence in the Late Pliocene [28], deposition on basin slopes, and proximity of terrigenous sediment and terrestrial organic matter sources from the inland.

The Quaternary (2.588 Ma to present), and notably the Pleistocene epoch (2.588-0.0117 Ma), was characterized by climate changes that caused several changes of life evolution and in palaeorelief. During the Pleistocene glacials, the volume of the total world ice was significantly larger than what it is today. Donn et al. [29] have calculated that in the Last Glacial Stage (abbr. LGS, i.e., Classical Wisconsin), the global sea level was lower than what it is today by about $105.5 \mathrm{~m}$ or $123.4 \mathrm{~m}$ (the precise value being dependent on the world ice vol- 

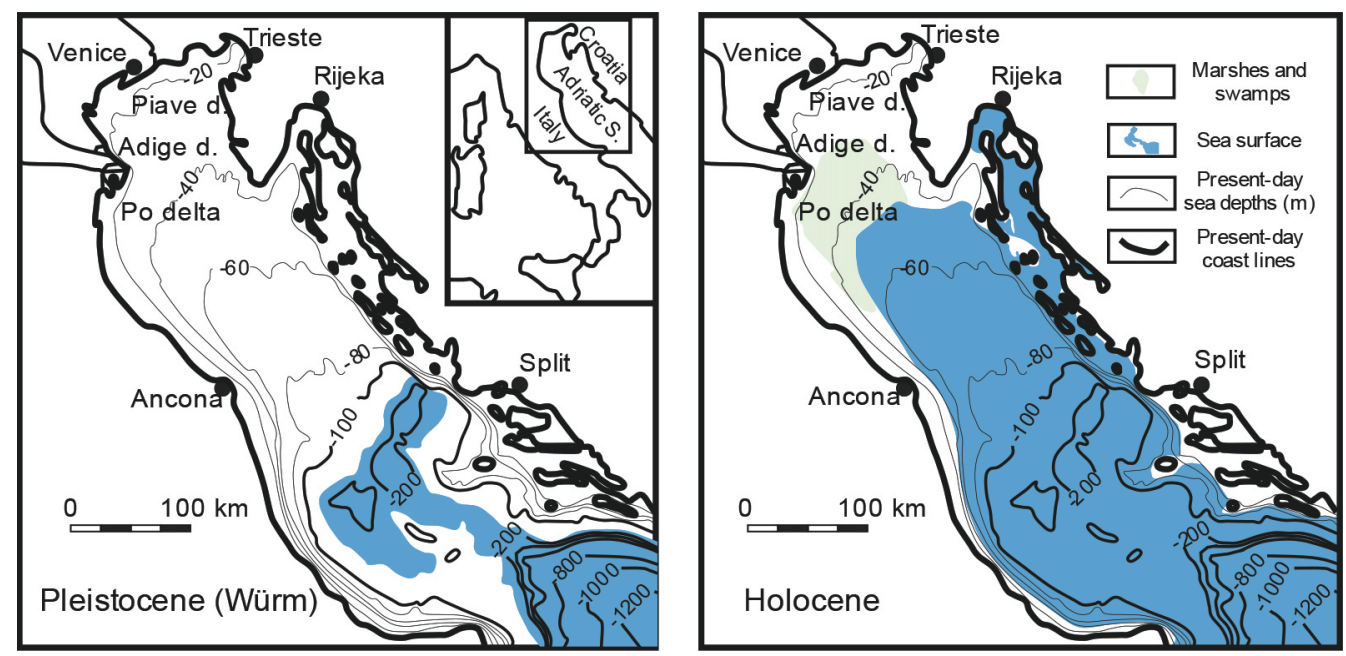

Figure 4: Borders of Adriatic Sea during Würm (111,000-11,700 y. ago) and Early Holocene (about 11,700 y.a.). The figure is slightly modified from Velić and Malvić [15] and Correggiari (1996).

ume); during the Third Glacial (Illinoian), the sea level was even lower, at between $137.4 \mathrm{~m}$ and $159.3 \mathrm{~m}$ below the present-day sea level. Yokoyama et al. [30] stated that ice volumes in the Last Glacial Maximum (LGM) exceed the present-day volumes by $52.5 \times 10^{6} \mathrm{~km}^{3}$ and also cited [31] conclusion, which is similar to [29], that globally, the sea level at the LGM was about 130 lower than what it is today. Pleistocene glaciations in the Alpine region were, of course, directly reflected in the palaeogeography of the Adriatic Sea. Land areas generally expanded in glacial periods (Figure 4), and continental environments were directly reflected in drainage areas and in the quantity of eroded detritus. Consequently, the margins of the Adriatic Sea were mostly influenced by Quaternary glacial and interglacial periods. When glaciers formed and advanced and sea level fell, many rivers, especially the palaeo Po, extended their drainage areas and formed significantly larger deltas and prodeltas. For example, the last glacial (Würm, 0.11-0.012 Ma) sea-level fall of up to $125 \mathrm{~m}$ meant that the northern Adriatic was mostly an inland terrestrial drained by river networks $[5,6,9]$.

The Po River remains the major transporter of detritus in the entire Adriatic Sea, reflecting both the very low sediment supply from the eastern Adriatic coast [32] and the substantial volumes transported from the western coast. Sediment supply from eastern Alpine rivers delivers $3 \times 10^{6} \mathrm{t} / \mathrm{yr}$, the Po River $15 \times 10^{6} \mathrm{t} / \mathrm{yr}$, and the eastern Apennine rivers north of the Gargano promontory deliver $32.2 \times 10^{6} \mathrm{t} / \mathrm{yr}$; $1.5 \times 10^{6} \mathrm{t} / \mathrm{yr}$ are delivered by rivers to the south of that promontory [33-36]. As result of glaciations, the eastern part of the Po delta and the entire prodelta prograded about $200 \mathrm{~km}$ and transported clastics into the present-day Croatian offshore in the area south-west of Istra Peninsula and the Kvarner islands. Consequently, the pre-glaciations, that is, Pliocene, which are turbiditic deposits in the Croatian part are missing (or very rare in Upper Pliocene) and represented by basinal hemipelagic clays and marlitic clays.

\section{Pliocene and Pleistocene depositional environments and processes}

During the Pliocene and Pleistocene, sediments in the Po Depression were mainly, as today, transported by the Po River and its tributaries, and partially by the Adige and Piave Rivers (which mostly supplied sediment to the Venetto Depression). Northern Adriatic Pliocene turbidites are mostly recognised as siltstone and sandstone sequences in the Italian part of the Po Depression. In the Croatian part, similar sediments are recognised only from the Pleistocene when the margins of the northern Adriatic were narrower and migrated eastwards, in response to glacial periods. Such progradation and retrogradation cycles of the palaeo Po are probably the best studied in the youngest Pleistocene and Holocene sediments due to the 
availability of sedimentary records [37]. These sediments are also recognised in regional seismic sections in Early Pleistocene deep water environments in part of the Venetto and Po Depressions and in the later north-east progradation of the palaeo Po delta during the Middle Pleistocene [38].

Pleistocene lithofacies are significantly different from those of the Pliocene due to common intervals of sands and silts. In the Croatian sector, permeable, turbiditic lithofacies are the most commonly recognised and described in cores from the reservoirs in the largest Ivana gas field, where a proven sequence of Pleistocene sediments, with a thickness between $900 \mathrm{~m}$ and $1,500 \mathrm{~m}$, is present [39]. Towards the deeper parts of the basin, thicknesses can be up to 2,000 m (see Figure 5 here or Figure 4.2 from [9], as modified from [27]). Such values are generally characteristics for deep Pleistocene turbiditic and deltaic complex in the Croatian part of the Po Depression. Moreover, Pleistocene deposits are divided into numerous depositional sequences of 4 th order. In the Italian part, 12 such intervals are recognised. However, in Croatia, 4 of them are outlined and they are named as Q1, Q2, Q3 and Q4 (the youngest) and all are of the Pleistocene age. The sandy content, sedimentation rate and influence of sea-level fluctuations are higher in the younger part of the sequences. Compositional analyses show that during the Q1 and Q2 depositional and part of the Q3 interval, the source area(s) of these units were dominantly carbonate rocks, whereas the younger Q3 and Q4 units are dominated by an Alpine mineralogical association transported by the palaeo Po from the Alps. The increase in sandy detritus in the upper part of Q2 is correlated with the lowering of the eustatic sea level [9]. Similarly, [40] correlated seismically traceable border (and also an event named as marine isotope stage 22 , abbr. MIS 22) with an age of $0.87 \mathrm{Ma}$ in the Po Plain subsurface and described it as the first prominent Pleistocene glacio-eustatic lowstand, dated at the end of Middle Pleistocene. This sequence border, seismically recognised, is also climatologically conditioned and marks the first Pleistocene glaciations in the Alps, that is, with significant changes in palaeoecological and climate depositional conditions.

\section{Lithostratigraphy nomenclature in the northern Adriatic}

Numerous new works and published results on Pliocene and Pleistocene deposition in the Croatian northern Adriatic have demonstrated the need to correct (1) the existing Croatian lithostratigraphic nomenclature and/or (2) the incorrect application to the Croatian northern Adriatic of Italian nomenclature developed for the Po Depression. The need for the first correction arises from using only one formation for the entire Cenozoic era, which is obviously an extreme simplification. The second issue reflects the different depositional conditions, especially during the Pliocene, in the Italian and Croatian sectors. For example, in the Croatian northern Adriatic, only the Pleistocene period is characterised by recognisable turbidite sequences. Indeed (and this is not a lithostratigraphic criterion), the distribution of such units often follows state borders, changing their names.

The differences in Pliocene and Pleistocene lithofacies and thicknesses in the Croatian offshore have been the basis for improvements in Croatian lithostratigraphic nomenclature in the northern Adriatic [15] (Figure 5). These formations are recognised in the Po Depression and can be compared with the marginal parts of the Dugi Otok Depression or even with thin sequences deposited on the exposed Mesozoic Adriatic Carbonate Platform. Revisions of the Pleistocene of the Croatian northern Adriatic by [9] have defined three additional members: an ' $\mathrm{A}$ ' Member that is correlated with the depositional sequences Q1, Q2 and part of Q3; a 'B' Member correlating with the upper Q3 sequence; and a ' $C$ ' Member correlating with Q4. Later, this nomenclature is eventually fully developed for all rocks and deposits developed from pre-platform, the Adriatic Carbonate Platform, post-platform and clastic dominated depositional systems as follows [41]:

- A pre-Adriatic Carbonate Platform succession ranging in age from Late Carboniferous (Middle Pennsylvanian: Moscovian) to Early Jurassic (Early Toarcian) as the Brušane and Baške Ostarije Formations;

- An Early Jurassic to Late Cretaceous platform megasequence as the Mali Alan Formation; 


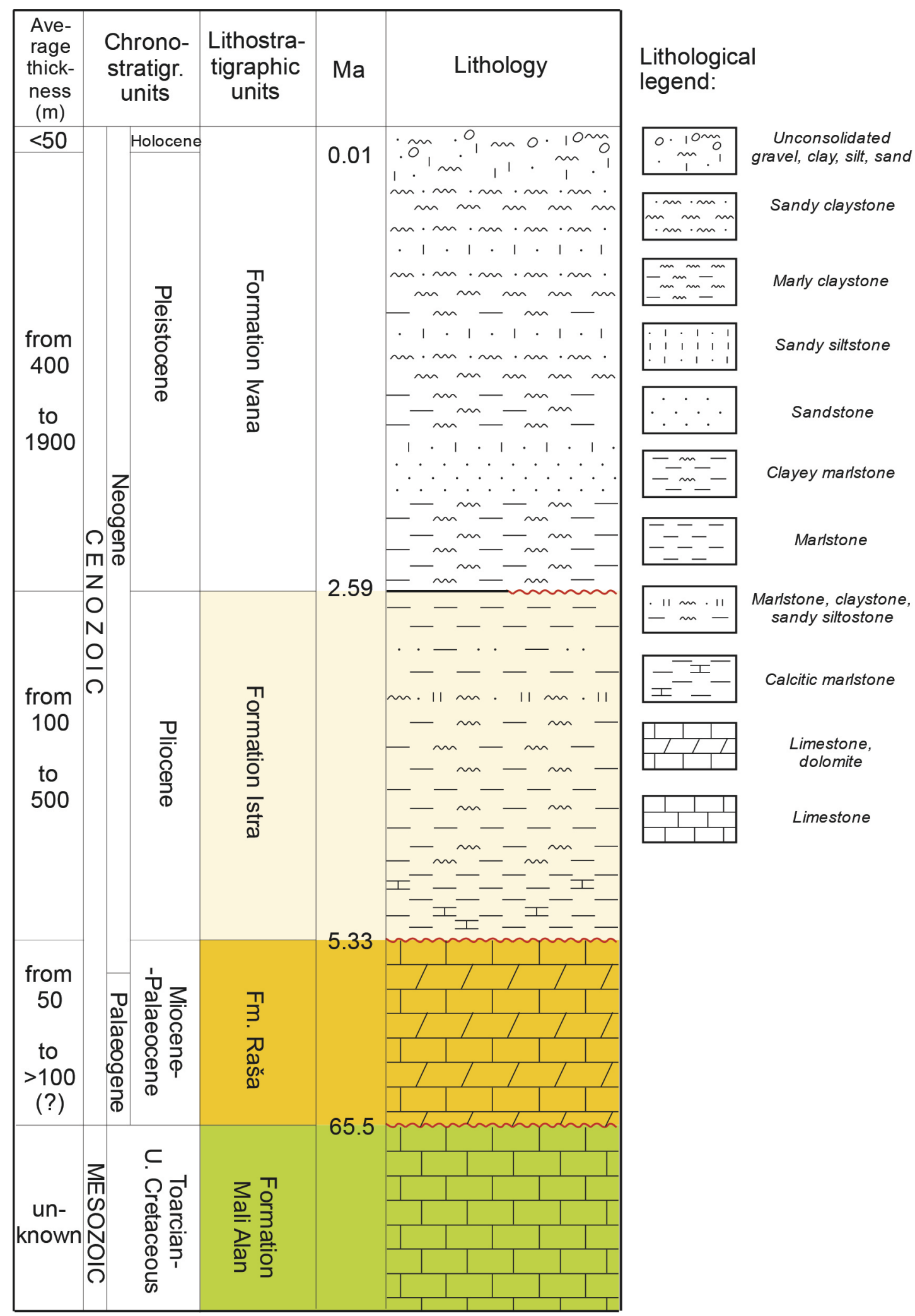

Figure 5: Lithostratigraphic nomenclature in northern Adriatic given from Velić and Malvić [15] and Velić et al. [41]. 


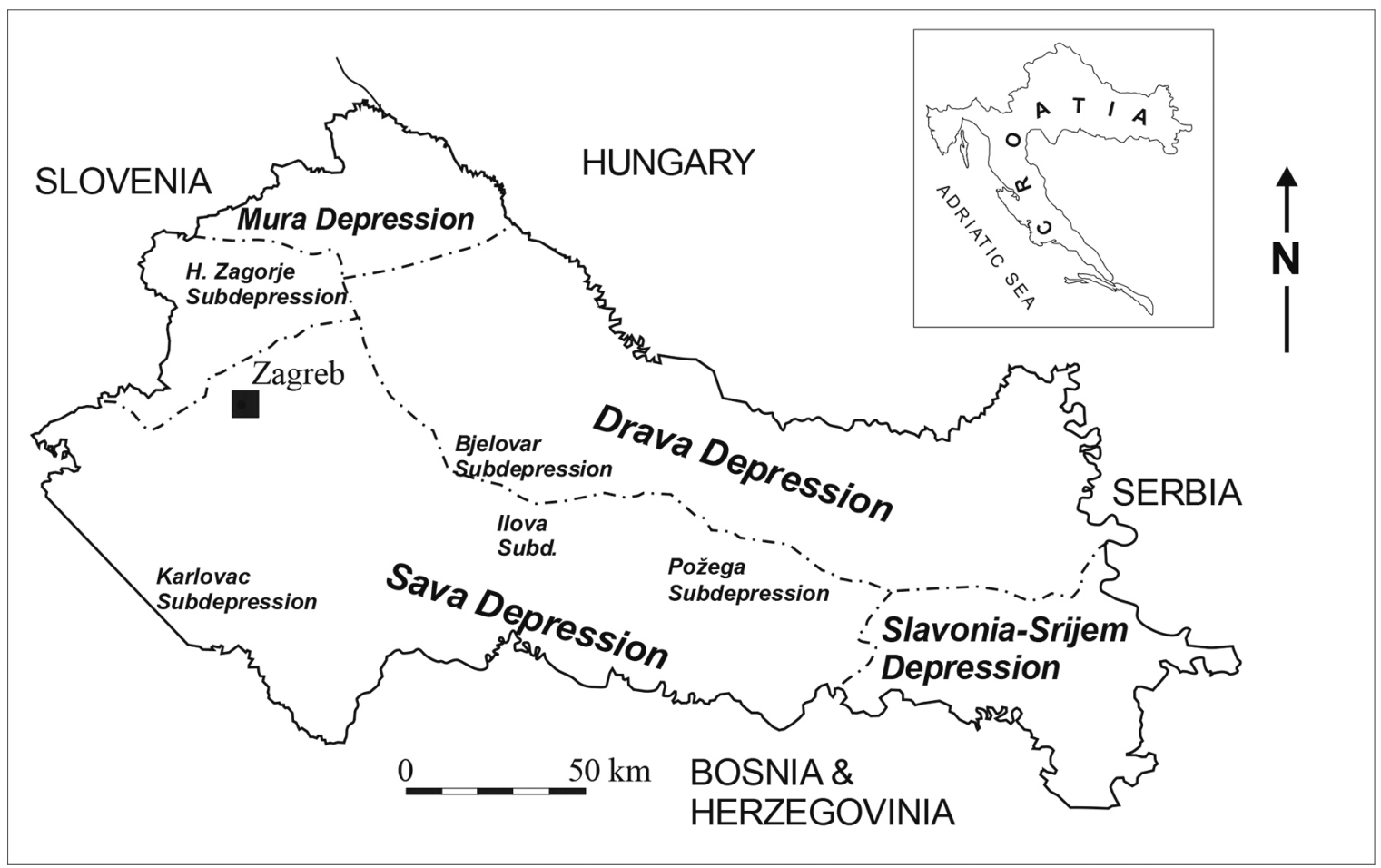

Figure 6: Neogene-Quaternary depressions in the Croatian part of the Pannonian Basin System.

- A Paleogene to Neogene post-platform megasequence as the Raša Formation;

- A Neogene to Quaternary (Pliocene to Holocene) megasequence as the Istra and Ivana formations.

Units listed as (i)-(iii) are valid for the entire Croatian part of the Adriatic Basin. The units listed as (iv) are local, valid in the Croatian northern Adriatic and could be partially correlated with other Pliocene and Pleistocene local clastic depositional environments along the Croatian offshore [32].

\section{Upper Miocene turbidite systems of the Croatian part of the Pannonian Basin System}

The Croatian part of the Pannonian Basin System (CPBS) approximately covers the northern part of Croatia (Figure 1) over an area of about 20,000 square $\mathrm{km}$. It is divided into four Neogene-Quaternary depressions, namely, the Drava, Sava, Mura and Slavonija-Srijem (Figure 6). The very NW area, the Hrvatsko zagorje Subdepression (Figure 6), is an area of smaller depressions (sub-basins). However, it is con- sidered tectonically either to be a border zone between the Alps, the Dinarides and the Pannonian Basin System [42] or to be solely part of Northern Croatia with Egerian and other Lower Miocene sediments [43], which are not characteristic of the CPBS.

\section{Upper Miocene depositional environments and processes}

In the Late Pannonian and Early Pontian (9.3$5.6 \mathrm{Ma}$ ), and locally even from the Early Pannonian, depressions in the CPBS (Figure 6) were elongated brackish lakes [44], sporadically connected by narrow tranches. Such depressions had been derived from Lake Pannon [45], which existed as an extensive lacustrine environment after the closure of the Central Paratethys $[2,44,46]$, transforming, in the Late Miocene, into an open lake system with active in-flows and out-flows of fresh water [47].

Sedimentation in Croatian brackish lakes was mostly described by simple heterogeneous deposition of two major lithofacies, which was supported with the Eastern Alps as the main psammitic detritus source. The continuous basin, hemipelagic (pelitic) deposition (calcite muds and clays), had been interrupted by 


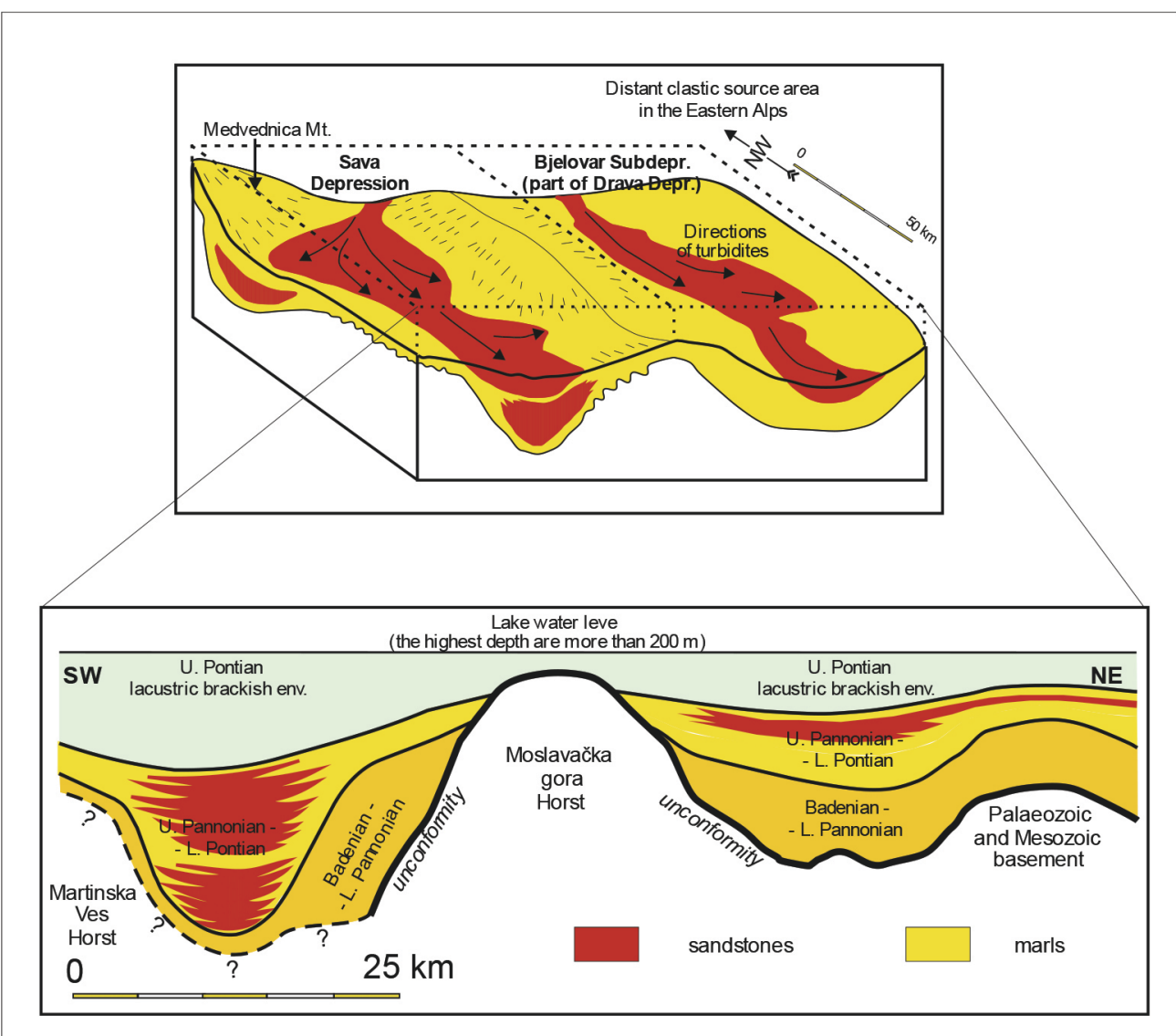

Figure 7: Schematic review of depositional environments, recent sediments and palaeo-directions of turbidites during Upper Pontian in the CPBS (slightly modified from Vrbanac et al. [4]).

medium and fine sands deposited by turbidity currents $[4,48,49]$. In general, most turbidites were deposited within particular 'strike-slip' structures that opened along the depression bottom. Reconstruction of the Neogene and Quaternary geological evolution of one such typical structure (the Kloštar Field) has been palinspastically mapped and explained by [50], and geological evolution during Neogene and Quaternary has been mapped onto a scale of entire (sub)depression [51-53]. Downwarped structures were depositional centres for the medium- and fine-grained sandy fraction in turbidity currents. Obviously, distally in the east as well as on the margins of 'strike-slips', transport energy was low and finer lithofacies were deposited, mostly consisting of silty sand, silt and clayey silt. This arrangement means that each depocentre is characterised by lithofacies that grade from medium-grained sandstones to marginal (i.e., basinal) marlstones [49, 54]. The Late Miocene also corresponds to the second depositional megacycle [1], when sandy, silty, calcitic and clayey detritus was deposited over a period of approximately 5.9 Myrs. This megacycle reaches a thickness in excess of $4,000 \mathrm{~m}$ in the deepest part of the Drava Depression.

The surrounding uplifted topography, mostly formed during Alpine orogenesis, often with horst elements, consisted of a relatively small inland area of several tens of square kilometres and was exposed to weathering. The restricted areal extent of this uplifted topography explains why it played a minor role [55] as the source of only small quantities of sands transported by alluvial fans into large brackish lakes, where deep turbidity currents deposited most detritus along the basin bottom.

The presence of type III kerogens and fossil sporomorphs is strongly indicative of the existence of a shallow environment by the Late Pannonian. Lakes were mostly up to $200 \mathrm{~m}$ deep with approximately equal rates of sedimentation and subsidence [4] (Figure 7). This 


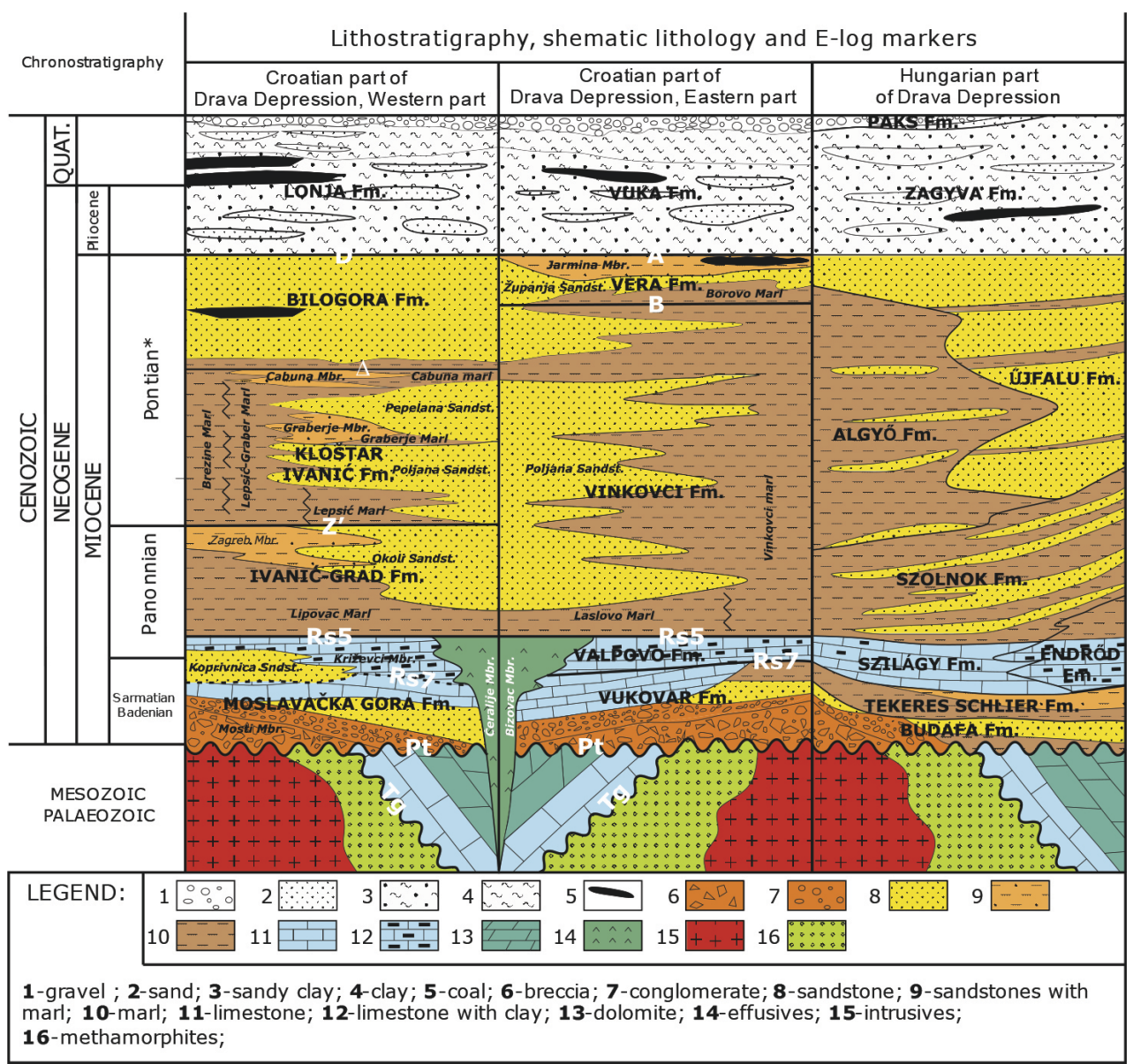

Figure 8: Lithostratigraphic nomenclature in the CPBS (from Malvić and Cvetković [56]).

period also coincided with the second transtensional phase in the CPBS [44], generally beginning in the Late Pannonian (9.3-7.1 Ma) and continuing throughout the Early Pontian (7.15.6 Ma). Successive turbidity current events were the main depositional mechanisms in the Late Miocene [4, 17, 18, 44], when clastics were transported from the Eastern Alps to the CPBS by turbidity currents initiated by gravitational instability (sometimes accompanied by faulting) caused by extremely large detritus masses along structural ramps. Such macrostructures are still located mostly along depressional margins. Each depositional episode transported clastics over tens of kilometres to deposit them into structurally determined depositional centres in the Mura, Sava, Drava and Slavonia-Srijem depressions. Each period of turbidite activity was followed by pelitic sedimentation in lacustrine environments, resulting in a regular alternating sequence of sandstone and marlstone lithofacies (Figures 7 and 8). The even- tually shallow lake environments in the Late Pontian changed to fresh water $[2,4,44]$.

\section{Lithostratigraphy nomenclature in the CPBS}

Generally, clastic and biogenic sediments filled all CPBS depressions from the Badenian to the Quaternary, reaching a total thickness of 7,000 m or more in the central part of the Drava Depression [2]. Middle Miocene volcanic rocks and fluvial and lacustrine sediments of Lower Miocene age are sporadically present. In the basement of the CPBS are rocks of significantly different lithology and chronostratigraphy. These are mostly carbonates (limestone and dolomite), metamorphites (amphibolite, schist and gneiss) and magmatites (granite, gabbro) from Mesozoic and Palaeozoic eras.

Šimon proposed lithostratigraphic division into formations and members for the Neogene-Quaternary interval, initially for hydrocarbon exploration and subsequently in his dissertation [48]. The most comprehensive review of the 
Croatian lithostratigraphic nomenclature in the CPBS is given by [2].

The lithostratigraphy of the largest parts of the CPBS can be easily correlated in all depressions. However, the eastern part of the Drava Depression is interesting as an area where Croatian and Hungarian units are correlated based on data from $[2,57,58]$ and published in [56]. The time scale follows [44, 59]. Lithostratigraphic interpretation indicates that this zone is transitional between turbidite-dominated sedimentation in the Croatian sector and delta/ prodelta-dominated deposition in the Hungarian part. These interpretations imply that the lithostratigraphy of the CPBS almost strictly can be correlated with chronostratigraphic stages and sub-stages in that area (Figure 8). On the contrary, in the Hungarian part, the lithostratigraphic borders of Neogene and Quaternary formations cannot vary in space and time, that is, they are asynchronous in terms of location. It is a direct consequence of what happened in Hungary depositions in delta and prodelta environments (Figure 8).

\section{Conclusion}

Turbidites are recognized in the clastics deposited in the Croatian part of the Po Depression as well as in the Croatian part of the Pannonian Basin System. Both these sedimentary systems belong to the Neogene and Quaternary periods and both have their main detritus sources in the Alps. Moreover, the north Adriatic and north Croatian turbidites dominantly consist of medium- to fine-grained sandstones. In both areas, particular turbidite sequences (events) usually reach several tens of metres in thickness. The next similarity is that all turbiditic activities and reflections in lithologies determine lithostratigraphic units in order of formations and members. In addition, such units are well correlated with chronostratigraphic periods (northern Adriatic) and sub-stages (Pannonian Basin System).

Differences also result from different environments (marine in the Adriatic vs. lacustrine in the Pannonian) and palaeogeography. The northern Adriatic represents a significantly wider area, where differences between axes (of the order of a hundred kilometres) were not so significant. This means that deltas were able to migrate through space and time, laterally as well as in the direction of progradation/ retrogradation. Consequently, in the northern Adriatic, different sequences can be followed, describing the migration of distal delta and prodelta environments, especially during the Late Pleistocene. By contrast, in the CPBS, deposition was active in long, narrow depressions (with width in the range of tens and length of hundred kilometres), where delta and prodelta systems could not develop. Turbidites were carried by pure gravitational flow and detritus was deposited in palaeogeographic (mostly tectonically-determined) structural lows. Consequently, the distribution of lithofacies is more complex, because each of such 'lows' is characterised by lateral transition from sandstone to marl lithofacies.

Moreover, the locations of delta and prodelta during the Pleistocene in the northern Adriatic were largely determined by glacial periods, when the Po River Basin was a periglacial basin. Conversely, during the Pliocene, tectonics and the development of the Apennine foreland played the main role in shaping deep water Early Pleistocene depositional environments with thick turbidite successions in the Italian part. The source areas for both regions were the Alps. However, Pliocene and Pleistocene detritus in the northern Adriatic was derived from the Southern Alps and partially from the Apennines and transported by the Po, Adige, and Piave Rivers, as well as by other smaller flows into marine environments along basin slope towards S and SE. On the contrary, turbidites in Northern Croatia were formed from detritus brought from the Eastern Alps and transported along structural ramps due to tectonic events and gravitational instabilities several tens of kilometres long.

\section{Acknowledgements}

The results presented here are also derived from the work developed during 2012 and 2013 as part of the project 'Stratigraphical and geomathematical research of petroleum geological systems in Croatia' (No. 195-1951293-0237, 
head J. Velić), financed by the Croatian Ministry of Science, Education and Sport. The final form had been derived with results obtained during support for researching 'Geomathematical researching and mapping of selected Croatian depositional environments from Holocene to Lower Miocene' (head T. Malvić) funded by the University of Zagreb in 2015.

\section{References}

[1] Velić, J., Weisser, M., Saftić, B., Vrbanac, B., Ivković, Ž. (2002): Petroleum-geological characteristics and exploration level of the three Neogene depositional megacycles in the Croatian part of the Pannonian Basin. Nafta, 53/6-7, pp. 239-249.

[2] Velić, J. (2007): Geologija ležišta nafte i plina [Geology of oil and gas reservoirs]. University of Zagreb, Faculty of Mining, Geology and Petroleum Engineering, Zagreb; 342 p. (in Croatian and English).

[3] Troskot-Čorbić, T., Velić, J., Malvić, T. (2009): Comparison of the Middle Miocene and the Upper Miocene source rock formations in the Sava Depression (Pannonian Basin, Croatia). Geol. Croat., 62/2, pp. 123133.

[4] Vrbanac, B., Velić, J., Malvić, T. (2010): Sedimentation of deep-water turbidites in main and marginal basins in the SW part of the Pannonian Basin. Geol. Carpathica, 61/1, pp. 55-69.

[5] Colantoni, P., Gallignani, P., Lenaz, R. (1979): Late Pleistocene and Holocene evolution of the North Adriatic Shelf (Italy). Mar. Geol., 33, pp. M41-M50.

[6] Fairbanks, R.G. (1989): A 17,000-year glacio-eustatic sea level record: influence of glacial melting rates on the Younger Dryas event and deep-ocean circulation. Nature, 342, pp. 637-642.

[7] Stanley, D.I. (1995): A global sea level curve for the late Quaternary: the impossible dream? Mar. Geol., 125, pp. 1-6.

[8] Vlahović, I., Tišljar, J., Velić, I., Matičec, D. (2005): Evolution of the Adriatic carbonate platform: palaeogeography, main events and depositional dynamics. Palaeogeogr., Palaeoclimatol., Palaeoecol., 220/3-4, pp. 333-360.

[9] Marić-Đureković, Ž. (2011): Litofacijesne i stratigrafske značajke pleistocenskih naslaga Sjevernog Jadrana na temelju visokorazlučivih karotažnih mjerenja [Lithofacies and stratigraphy of Pleistocene deposits in North Adriatic offshore by using high-resolution well logs]. PhD thesis. Zagreb: University of Zagreb, Fac- ulty of Mining, Geology and Petroleum Engineering, Croatia, 2011; 167 p. (in Croatian with English abstracts).

[10] Prelogović, E., Kranjec, V. (1983): Geološki razvitak područja Jadranskog mora [Geological evolution of the Adriatic Sea]. Pomorski zbornik, 21, pp. 387-405 (in Croatian and English).

[11] Middleton, G.V. (1967): Experiments on density and turbidity currents. III. Deposition of sediment. Can. J. Earth Sci., 4, pp. 475-505.

[12] Middleton, G.V., Hampton, M.A. (1976): Subaqueous sediment transport and deposition by sediment gravity lows. In: Stanley, D.J., Swift, D.J.P. (Eds.) Marine Sediment Transport and Environmental Management. John Wiley, New York, pp. 97-218.

[13] Lowe, D.R. (1976): Subaqueous liquefied and fluidized sediment flows and their deposits. Sedimentology, 23, pp. 285-308.

[14] Lowe, D.R. (1979). Sediment gravity flows: their classification and some problems of application to natural flows and deposits. In: Society of Economic Paleontologists and Mineralogists, Special Publication No. 27, pp. 75-82.

[15] Velić, J., Malvić, T. (2011): Depositional conditions during Pliocene and Pleistocene in Northern Adriatic and possible lithostratigraphic division of these rocks [Taložni uvjeti tijekom pliocena i pleistocena u Sjevernom Jadranu te moguća litostratigrafska raščlamba nastalih stijena]. Nafta, 62/1-2, pp. 25-38 (in English and Croatian).

[16] Vrbanac, B. (1996): Paleostrukturne i sedimentološke analize gornjopanonskih naslaga formacije Ivanić grad u savskoj depresiji [Palaeostructural and sedimentological analyses of Late Pannonian sediments of Ivanić Grad formation in the Sava depression]. PhD thesis. Zagreb: University of Zagreb, Faculty of Natural Sciences, 1996; 121 p. (in Croatian with English summary).

[17] Vrbanac, B. (2002a): Chronohorizons based on resistivity curve variations - Upper Miocene sediments of the Ivanić Grad Formation in the Sava Depression (NW Croatia). Geol. Croat., 55/1, pp. 11-24.

[18] Vrbanac, B. (2002b): Facies and facies architecture of the Ivanić Grad Formation (Upper Pannonian) - Sava Depression, NW Croatia. Geol. Croat., 55/1, pp. 57-78.

[19] Bouma, A.H. (1962): Sedimentology of Some Flysch Deposits: A Graphic Approach to Facies Interpretation. Elsevier, Amsterdam, New York; 1968 p.

[20] Van Der Lingen, G.J. (1969): The turbidite problem. N.Z.J. Geol. Geophys., 12, pp. 7-50. 
[21] Kennett, J.P. (1977): Cenozoic evolution of Antarctic glaciation, the circum-Antarctic Ocean, and their impact on global paleoceanography. J. Geophys. Res., C: Oceans Atmos., 82/27, pp. 3842-3860.

[22] Mercer, J.H., Sutter, J.F. (1982): Late Miocene-earliest pliocene glaciation in southern Argentina: implications for global ice-sheet history. Palaeogeogr., Palaeoclimatol., Palaeoecol., 38/3-4, pp. 185-206.

[23] Veseli, V. (1999): Facijesi karbonatnih sedimenata mlađeg mezozoika i paleogena u pučinskim bušotinama sjevernog Jadrana [Carbonate facies of the Late Mesozoic and Palaeogene in offshore wells from northern Adriatic Sea]. PhD thesis, Zagreb: University of Zagreb, Faculty of Mining, Geology and Petroleum Engineering, 1999; 306 p. (in Croatian and English).

[24] Thunel, M. (1971): Građa tercijarnog bazena u sjeveroistočnom dijelu Jadranskog mora [Settings of Tertiary basin in northeastern part of the Adriatic Sea]. Nafta, 22/4-5, pp. 275-434 (in Croatian and English).

[25] Cita, M.B., Ryan, W.B.F. (1972): The Pliocene Record in Deep Sea Mediterranean Sediments. Times-scale and General Synthesis, Initial Reports DSDP, Washington.

[26] Kalac, K. (2008): Biostratigrafsko-kronostratigrafska istraživanja pliocensko-pleistocenskih naslaga u podmorju Jadrana s posebnim osvrtom na klimatske promjene [Biostratigraphy and chronostratigraphy researches of Pliocene-Pleistocene deposits in the Adriatic offshore with special emphasis on climate changes]. Naftaplin, 45/8, 104 p. (in Croatian and English).

[27] Mattavelli, L., Novelli, L., Anelli, L. (1991): Occurrence of hydrocarbons in the Adriatic basin. In: Spencer, A.M. (Ed.) Generation, Accumulation and Production of Europe's Hydrocarbons. Special Publication of the European Association of Petroleum Geoscientists, No. 1, Oxford University Press, Oxford, pp. 369-380.

[28] Rio, D., Channel, J.E.T., Bertoldi, R., Poli, M.S., Vergerio, P.R., Raffi, I., Sprovieri, R., Thunell, R.C. (1997): Pliocene sapropels in the northern Adriatic area: chronology and paleoenvironmental significance. $\mathrm{Pa}$ laeogeogr., Palaeoclimatol., Palaeoecol., 135, pp.1-25.

[29] Donn, W.L., Farrand, W.R., Ewing, M. (1962): Pleistocene ice volumes and sea-level lowering. J. Geol., 70/2, pp. 206-214.

[30] Yokoyama, Y., De Deckker, P., Lambeck, K., Johnston, P., Fifield, L.K. (2001): Sea-level at the Last Glacial Maximum: evidence from northwestern Australia to constrain ice volumes for oxygen isotope stage 2. Palaeogeogr., Palaeoclimatol., Palaeoecol., 165, pp. 281-297.
[31] Nakada, M., Lambeck, K. (1988): The melting history of the Late Pleistocene Antarctic ice sheet. Nature, 333, pp. 36-40.

[32] Balić, D., Malvić, T. (2013): Pliocene-Quaternary deposition and stratigraphy of the Neretva River Mouth, example of the Croatian Adriatic Coast. Geol. Q., 57/2, pp. 233-242.

[33] Frignani, M., Langone, L. (1991): Accumulation rates and ${ }^{137} \mathrm{Cs}$ distribution in sediments of the Po River delta and the Emilia-Romagna coast (north western Adriatic Sea, Italy). Cont. Shelf Res., 11, pp. 525-542.

[34] Milliman, J.D., Syvitski, J.P.M. (1992): Geomorphic/ tectonic control of sediment discharge to the ocean: the importance of small mountainous rivers. J. Geol., 100, pp. 525-544.

[35] Sorgente, D. (1999): Studio della sedimentazione attuale e recente nel medio Adriatico attraverso l'uso di traccianti radioattivi [Study of the current and recent sedimentation in the medium Adriatic through the use of radioactive tracers]. PhD thesis, Bologna: University of Bologna. Italy, 1999; 178 p. (in Italian).

[36] Cattaneo, A., Correggiari, A., Langone, L., Trincardi, F. (2003): The late-Holocene Gargano subaqueous delta, Adriatic shelf: sediment pathways and supply fluctuations. Mar. Geol., 193, pp. 61-91.

[37] Storms, J.E.A., Weltjea, G.J., Terrab, G.J., Cattaneoc, A., Trincardid, F. (2008): Coastal dynamics under conditions of rapid sea-level rise: late Pleistocene to early Holocene evolution of barrier-lagoon systems on the northern Adriatic shelf (Italy). Quat. Sci. Rev., 27/1112, pp. 1107-1123.

[38] Tosi, L., Teatini, P., Brancolini, G., Zecchin, M., Carbognin, L., Affatato, A., Baradello, L. (2012): Three-dimensional analysis of the Plio-Pleistocene seismic sequences in the Venice Lagoon (Italy). J. Geol. Soc., 169, pp. 507-510.

[39] Đureković, M., Krpan, M., Pontiggia, M., Ruvo, L., Savino, R., Volpi, B. (1998): Geological modelling and petrophysical characterisation of turbiditic reservoirs of the Ivana gas field - R. Croatia. Nafta, 49/7-8, pp. 241-258.

[40] Muttoni, G., Carcano, C., Garzanti, E., Ghielmi, M., Piccin, A., Pini, R., Rogledi, S., Sciunnach, D. (2003): Onset of major Pleistocene glaciations in the Alps. Geology, 31/11, pp. 989-992.

[41] Velić, J., Malvić, T., Cvetković, M., Velić, I. (2015): Stratigraphy and petroleum geology of the Croatian part of the Adriatic Basin. J. Pet. Geol., 38/3, pp. 281-300.

[42] Tomljenović, B., Csontos, L. (2001): Neogene-Quaternary structures in the border zone between Alps, Dinarides and Pannonian Basin [Hrvatskozagorje 
and Karlovac Basins, Croatia]. Geol. Rundsch., 90/3, pp. 560-578.

[43] Pavelić, D., Avanić, R., Kovačić, M., Vrsaljko, D., Miknić, M. (2003): An outline of the evolution of the Croatian part of the Pannonian Basin System. In: Vlahović, I., Tišljar, J. (Eds.) Evolution of Depositional Environments from the Paleozoic to the Quaternary in the Karst Dinarides and the Pannonian Basin. 22nd IAS Meeting of Sedimentology, September 17-19, Field Trip Guidebook, Opatija, 2003, pp. 155-161.

[44] Malvić, T., Velić, J. (2011): Neogene tectonics in Croatian part of the Pannonian Basin and reflectance in hydrocarbon accumulations. In: Schattner, U. (Ed.) New Frontiers in Tectonic Research: At the Midst of Plate Convergence. InTech, Rijeka, pp. 215-238.

[45] Magyar, I., Radivojević, D., Sztanód, O., Synake, R., Ujszászia, K., Pócsika, M. (2013): Progradation of the paleo-Danube shelf margin across the Pannonian Basin during the Late Miocene and Early Pliocene. Global Planet. Change, 103, pp. 168-173.

[46] Royden, L.H. (1988): Late Cenozoic tectonics of the Pannonian Basin System. AAPG Memoirs 45, AAPG, Tulsa, pp. 27-48.

[47] Bérczi, I., Hamor, G., Jambor, A., Szentgyörgyi, K. (1988): Neogene sedimentation in Hungary. In: Royed, L.H., Horváth, F. (Eds.), The Pannonian Basin. AAPG, Memoir. 45, AAPG, Tulsa, pp. 57-67.

[48] Šimon, J. (1980): Prilog stratigrafiji i taložnom sustavu pješčanih rezervoara Sava-grupe mlađeg tercijara u Panonskom bazenu Sjeverne Hrvatske [Contribution to stratigraphy of sandstone reservoirs depositional system in the Sava Group sediments in Late Tertiary of Pannonian basin in the Northern Croatia]. PhD thesis, Zagreb: University of Zagreb, Faculty of Mining, Geology and Petroleum Engineering, 1980; 56 p. + 82. encl. (in Croatian and English).

[49] Malvić, T. (2012): Review of Miocene shallow marine and lacustrine depositional environments in Northern Croatia. Geol. Q., 56/3, pp. 493-504.

[50] Malvić, T., Jović, G. (2012): Thickness maps of Neogene and Quaternary sediments in the Kloštar Field (Sava Depression, Croatia). J. Maps, 8/3, pp. 260-266.

[51] Velić, J. (1980): Geološka građa zapadnog dijela Savske depresije [Geological framework of the western part of the Sava Depression]. PhD thesis, Zagreb: University of Zagreb, Faculty of Mining, Geology and Petroleum Engineering, 1980; 137 p. (in Croatian with English summary).

[52] Malvić, T. (2003): Naftnogeološki odnosi i vjerojatnost pronalaska novih zaliha ugljikovodika u bjelovarskoj uleknini [Oil-Geological Relations and Prob- ability of Discovering New Hydrocarbon Reserves in the Bjelovar Sag]. PhD thesis, Zagreb: University of Zagreb, Faculty of Mining, Geology and Petroleum Engineering, 2003; 123 p. (in Croatian and English).

[53] Malvić, T., 2011. Geological maps of Neogene sediments in the Bjelovar Subdepression (Northern Croatia). J. Maps, 7/1, pp. 304-317.

[54] Novak Zelenika, K., Cvetković, M., Malvić, T., Velić, J., Sremac, J., 2013a. Sequential Indicator Simulations maps of porosity, depth and thickness of Miocene clastic sediments in the Kloštar Field, Northern Croatia. J. Maps, 9/3, pp. 1-8.

[55] Novak Zelenika, K., Velić, J., Malvić, T. (2013b): Local sediment sources and palaeoflow directions in Upper Miocene turbidites of the Pannonian Basin System (Croatian part), based on mapping of reservoir properties. Geol. Q., 57/1, pp. 17-30.

[56] [56] Malvić, T., Cvetković, M. (2013): Lithostratigraphic units in the Drava Depression (Croatian and Hungarian parts) - a correlation [Korelacija litostratigrafskih jedinica u Dravskoj depresiji (hrvatski i mađarskidio)]. Nafta, 64/1, pp. 27-33. (in English and Croatian).

[57] Juhász, Gy. (1998): A magyarországi neogén mélymedencék pannóniai képződményeinek litosztatigráfiája [Stratigraphy of Neogene Formations from Deep Basin]. In: Bérczi, I., Jámor, Á. (Eds.) Magyarország Geológiai Képződményeinek Rétegtana [Stratigraphy of Hungarian Geological Formation]. MOL Rt and MÁFI, Budapest, pp. 469-484.

[58] Korpásné-Hódi, M. (1998): A medenceperemi Pannóniai S.L. üledékes formációk rétegtana [Statrigraphy of Pannonian Formations from Marginal Basin]. In: Bérczi, I., Jámor, Á. (Eds.) Magyarország Geológiai Képződményeinek Rétegtana [Stratigraphy of Hungarian Geological Formation]. MOL Rt and MÁFI, Budapest, pp. 453-468.

[59] Haq, B.U., Eysinga, F.W.B. (Eds.) (1998): Geological Time Table, Fifth Edition (Wall Chart). Elsevier Science, Amsterdam. 
